\title{
ERRATA
}

\section{Immunogenicity of Subcellular Fractions from \\ Yeast Cells of Histoplasma capsulatum}

Ram P. Tewari and Robert LaFemina

Department of Medical Microbiology and Immunology, Southern Illinois Vniversity School of Medicine, Springfield, Illinois 62708 , U.S.A.

Volume 24, no. 3, p.179, abstract, line 2 from bottom : "ritht" should read "right", and line 1 from bottom: "veccine" should read "vaccine".

24 巻 3 号, p. 179, 抄録に誤植がありましたので下記のように訂正致します.

下から 2 行目 ritht $\rightarrow$ right

下から 1 行目 veccine $\rightarrow$ vaccine

\section{謝 辞}

私は昭和 52 年 11 月から昭和 58 年 10 月迄 3 期 6 年間本誌の編集委員長をつとめてまいりました。こ の間編集委員として御協力下さいました，金原武司，篠田孝子，西本勝太郎，宮治 誠，山口英世， 渡辺一功, 高橋 久, 直江史郎, 三上 襄, 田中健治, 西川武二, 広永正紀の諸先生に心から感謝 申し上げます。また編集事務に御協力いただきました，加賀谷けい子，西川朱實，池田玲子，清水 あつこの諸氏に厚く御礼申し上げます。

前編集委員長

深 沢 義 村 